УДК 347.963:659.3

DOI https://doi.org/10.32849/2663-5313/2020.3.55

Володимир Клочков, канд. юрид. наук, докторант

Національного транспортного університету, стариий радник юстииї, прокурор відділу Головного слідчого управління Генеральної прокуратури України

\title{
ВЗАЕМОДІЯ ГЕНЕРАЛЬНОЇ ПРОКУРАТУРИ ІЗ ЗАСОБАМИ МАСОВОЇ ІНФОРМАЦІЇ
}

У статті розглянуто та наголошено на необхідності взаємодії Генеральної прокуратури із засобами масової інформаиї, спрямованої на реалізачію принципу гласності, охорону та захист прав і свобод людини, інтересів держави.

Обгрунтовано, шо формами взаємодії прокуратури із засобами масової інформаиї є: пресконференція, розміщення матеріалів у засобах масової інформацї; брифінг; поширення прес-релізів; інтерв'ю; «круглий стіл»; прес-тур; розміщення інформаиійних матеріалів на вебсайті; виступи працівників у телевізійнх ефірах та радіопрограмах; розміщення інформаційних матеріалів у нових медіа; запрошення представників засобів масової інформачї̈ на службові нараді. Зокрема, інформування населення має поєднуватися з правопросвітницьким напрямом, спрямованим на подолання правового нігілізму, усунення негативного і правильного уявлення в суспільній свідомості про роль і значення прокуратури в системі органів державної влади, результатів правоохоронної діяльності.

Відзначимо, що прокурор перебуває під критикою масмедіа. Провокачійні запитання журналістів та інших представників засобів масової інформацї, категоричні вимоги до відповідей щодо кримінальних проваджень адресуються пращівникам прокуратури. У зв'язку з цим визначено, що працівники прокуратури мусять мати високий професіоналізм, що своєю чергою сприятиме правильному та обгрунтованому формулюванню відповідей на поставлені запитання журналістів та інших представників засобів масової інформацї, мають дотримуватися етики публічних виступів і вимог щодо надання службової та конфідениійної інформацї.

У статті наголошуеться на розслідуванні кримінальних правопорушень із залученням засобів масової інформаиї. Формою взаємодї є розмішення інформачійних матеріалів у нових медіа. Зокрема, слова «нові медіа» походять від англ. пеш тедіа, що належать до інтерактивних електронних видань та нових форм комунікацї (електронна пошта, соціальні мережі, відео- $і$ фотосервіси, блогінги, форуми тошо). Нові медіа досяжні на иифрових пристроях і дають користувачам можливість участі у створенні та поширенні інформащії. Інтерактивність означає спроможність иифрової системи реагувати на дії користувача, у зв'язку з чим на екрані відбуваються зміни візуальних елементів, тексту тощо.

Ключові слова: форми взаємодії, Генеральна прокуратура, засоби масової інформації, журналісти, гласність, права людини, злочин.

Постановка проблеми. У діяльності Генеральної прокуратури та підпорядкованих їй прокуратурах актуальним питанням $€$ взаємодія із засобами масової інформації щодо охорони, захисту прав і свобод людини, інтересів суспільства та держави.

Інформаційну діяльність системи прокуратури необхідно здійснювати на реалізацію принципу гласності, що є одним із важливих засобів зміцнення законності та сприяння підвищенню довіри у державі до цієї інституції.

Виникає питання: що є засобами масової інформації? До ЗМІ належать: матеріальні та інші носії інформації, органи та організації, зареєстровані відповідно до закону, які забезпечують публічне поширення друкованої та аудіовізуальної інформації.

В Україні відбувається багато процесів, що викликають резонанс у суспільстві. Працівники поліції опинаються у центрі подій. Встановлені факти силового протистояння груп людей, які беруть участь у масових заходах, мітингах, акціях протесту та дотримуються протилежних політичних поглядів та громадянської позиції.

Журналісти звертаються до системи прокуратури та поліції щодо спроб перешкодити їм виконувати свої професійні обов'язки.

Тому дієвою процедурою на попередження, реагування на факти перешкоджання 
законній професійній діяльності журналістів є ст. 171 КК України.

Працівники системи МВС мають бути толерантними, сприяти законній діяльності масмедіа, оскільки вони збирають суспільно важливу інформацію, яку мають донести до широкого загалу.

На підставі інформації журналістів щодо злочинів відкриті та розслідувані кримінальні провадження, за деякими з них є обвинувальні вироки.

Важливим не тільки для Генеральної прокуратури, а й всієї системи прокуратури $€$ визначення форм взаємодії із засобами масової інформації, що дає можливість більш відкритої та ефективної їх діяльності.

3 огляду на те, що цю форму взаємодії між різними органами державної влади не досить науково досліджено, автор багато років займається цією проблемою. 3 цією метою науково обгрунтував певні загальні елементи форм взаємодії [1].

Однак у кожної гілки влади, міністерства, відомства є свої функції та повноваження, передбачені відповідним законом, але у них зміст діяльності різний, а тому є специфіка в їхній роботі.

У зв'язку з цим підготовлено та опубліковано 18 статей щодо взаємодії Генеральної прокуратури з відповідними органами державної влади.

Метою дослідження $є$ визначення форм взаємодії Генеральної прокуратури України із засобами масової інформації.

Виклад основного матеріалу дослідження. До форм взаємодії Генеральної прокуратури України із засобами масової інформації належить прес-конференція, яка являє собою збори журналістів та інших представників засобів масової інформації, на якій мають бути Генеральний прокурор окремо або спільно із його заступниками, начальниками департаментів, управлінь та їх заступниками, можливо, начальниками відділів. Вони виступають 3 різних питань про стан законності, злочинності, у тому числі захисту прав і свобод людини, підбивають підсумки роботи, інформують про кримінальні провадження, які мають суспільний резонанс, відповідають на різні запитання.

Велике значення має високий професіоналізм цих прокурорських працівників, які зможуть правильно та обгрунтовано сформулювати відповіді на запитання журналістів та інших представників засобів масової інформації.

Під час підготовки до прес-конференції необхідно підтримувати контакти з акредитованими журналістами, від яких можливо дізнатися відповідну інформацію.
На запитання, які будуть мати суспільний резонанс, можливо скласти варіант відповіді.

Навіть деякі Президенти відповідних держав на запитання журналістів у ході пресконференцій з метою обгрунтованих відповідей читають підготовлену інформацію, роздруковану на папері.

Використовуючи цю форму взаємодії, слід звернути увагу на правило, яке існувало в радянські часи.

Не допускати поширення інформації щодо особи, яка має статус підозрюваного, обвинуваченого, до набрання законної сили обвинувального вироку.

Розміщення матеріалів у засобах масової інформації. Сутність такої взаємодії полягає в розміщенні в ЗМІ відповідних матеріалів прокурорсько-слідчої діяльності у формі інформаційно-аналітичного матеріалу, а саме статей, коментарів тощо.

Інформування населення має поєднуватися 3 правопросвітницьким напрямом, спрямованим на подолання правового нігілізму, усунення негативного ставлення і вироблення правильного уявлення в суспільній свідомості про роль і значення прокуратури в системі органів державної влади, результатів правоохоронної діяльності.

Подання важливої інформації дає змогу підвищити рівень правової культури населення, налагодити партнерську взаємодію з інститутами громадянського суспільства.

В інформаційних матеріалах мають бути об’єктивні дані, а не сенсаційні твердження.

Крім того, слід поширювати рубрики на правові теми у засобах масової інформації, у яких мають бути статті працівників системи прокуратури.

За наявності актуальної інформації автор цієї статті бере участь у роботі у цьому напрямі.

Так, підготовлено багато статей, які надруковані у відповідних газетах, журналах, у тому числі фахових, а в підсумку - понад 231 [2].

Автор тривалий час працював слідчим, старшим слідчим прокуратур, слідчим 3 особливо важливих справ прокуратури СРСР, в.о. начальника слідчого відділу Київської міжобласної спеціальної прокуратури, а тому добре знає проблеми досудового слідства, а також шляхи їх вирішення.

У слідчих не вистачає часу для розслідування злочинів, але вони мають діяти законно, обгрунтовано, швидко, викоріняти тяганину.

У радянські часи та на початку незалежності України були вимоги щомісяця розслідувати злочини не менш ніж у трьох кримінальних справах, які необхідно закінчити у встановлений строк. 
Автор цієї статті закінчував і більше 6 кримінальних справ у місяць, коли працював слідчим районних прокуратур.

Навіть за 3 дні закінчив розслідування злочинів у декількох кримінальних справах, за якими судами винесено обвинувальні вироки.

Тому звертаю увагу, що розслідування кримінальних правопорушень - дуже актуальна системна проблема. Автор досліджував цю проблему, за результатом якої надрукована стаття, за яку визнаний кращим автором 1999.

На семінарі прокурорів, згідно з підготовленою науковою статтею, зроблено доклад [3].

Автор створив музей історії прокуратури в Генеральній прокуратурі, а потім в Академії прокуратури України, який відвідували журналісти [4].

Більш того, до заступника Генерального прокурора України звернувся керівник відповідного журналу, щоб центральний апарат підготував та направив статтю у цей журнал. Виконати завдання доручалось різним управлінням. Але, враховуючи те, що я займаюсь науковою діяльністю, друкую статті в різних журналах та газетах, мені було доручено підготувати таку статтю, що було зроблено. Керівник структурного підрозділу уважно вивчив статтю про кримінальну відповідальність за викрадання державного майна, повністю погодився з ії̈ змістом [5].

До форми взаємодії належить брифінг (від англ. Briefing - недовгий, короткий), який здійснюється з метою оприлюднення позиції з одного питання. Брифінг дає можливість швидко повідомити суспільство про актуальне питання. Він організовується в умовах резонансних подій, коли виникає необхідність інформування про це суспільства та вжиття заходів. Інформування на брифінгу до 30 хвилин проводить одна особа (Генеральний прокурор або інша уповноважена особа).

Слід звернути увагу читачів та працівників, які здійснюють підготовку до цього заходу, що процедура брифінгу не передбачає спілкування з журналістами у форматі «запитання - відповідь». Якщо таке відбувається, а також порушені інші елементи процедури (структури) брифінгу, наприклад виступають заступники Генерального прокурора, а також начальник управління більше 30 хв., то це вже прес-конференція.

Іншою формою взаємодії є поширення прес-релізів, тобто повідомлення для преси, інформаційне повідомлення. Така форма $€$ інформуванням суспільства про певні події або офіційну реакцію Генеральної прокура- тури. Вони мають бути лаконічними за обсягом та містити інформацію лише про одну подію. Поширюються серед журналістів на брифінгах і прес-конференціях або надсилаються до редакцій, у тому числі електронною поштою з одночасним розміщенням на офіційному вебсайті Генеральної прокуратури України.

Наступною формою взаємодії є інтерв’ю. Сутність його полягає в одержанні інформації журналіста (інтерв'юера) від респондента у форматі «запитання-відповідь» 3 фіксацією відповідей, а потім оприлюдненням у засобах масової інформації.

В інтерв’ю висвітлюються не тільки результати роботи, але й проблеми правоохоронної та правозахисної діяльності, шляхи їх вирішення, що своєю чергою відображає рівень професійної підготовки та підбору окремих працівників прокуратури. Так, є факти, коли в Генеральну прокуратуру працевлаштовуються працівники, які жодного дня не працювали в системі прокуратури. Вони не зможуть на високому рівні здійснювати нагляд за законністю в певному напрямі відповідно до функцій та повноважень, передбачених ЗУ «Про прокуратуру», або контролювати діяльність підлеглих працівників, оскільки відсутній досвід.

Для обгрунтованого підтвердження цієї тези можна навести такий приклад: якщо особа має медичну освіту за спеціальністю окуліста, то вона не може працювати хірургом або зробити кваліфіковано операцію на серці, оскільки це інший напрям та специфіка медичного обслуговування.

Наявний конкурсний відбір кадрів до системи прокуратури слід удосконалювати. Необхідні нові підходи в підборі, підготовці та виховуванні кадрів.

«Круглий стіл», що відсвітлюється засобами масової інформації.

Така форма взаємодії здійснюється 3 метою колегіального розгляду складних проблем. Він не завжди є процедурою прийняття відповідних рішень. «Круглий стіл» належить до освітнього, інформаційнороз'яснювального публічного заходу. Під час його проведення здійснюється публічне обговорення окремих питань у межах висвітлення теми.

Прес-тур є заходом для журналістів, який поєднує прес-конференцію з відвідуванням певних об'єктів. Ця форма взаємодії із засобами масової інформації використовується для ширшого ознайомлення з діяльністю прокуратури, функціями, завданнями, повноваженнями прокурорів, результатами робіт окремих прокуратур, станом 
координаційної діяльності у сфері боротьбі зі злочинністю тощо.

Виступи працівників Генеральної прокуратури в телевізійних ефірах та радіопрограмах. Така форма взаємодії здійснюється 3 метою інформування суспільства про стан законності, зміцнення довіри населення до системи прокуратури. При цьому необхідно використовувати лаконічні словосполучення, уникати громіздких незрозумілих термінів для слухачів.

Важливою формою взаємодії є розміщення інформаційних матеріалів на вебсайті Генеральної прокуратури. Вони класифікуються на статистичні, динамічні, потокові.

До класифікації статистичних належать матеріали, які актуальні протягом тривалого часу. Їх розміщують у вигляді сторінок, що містять текстові, графічні та інші елементи.

До класифікації динамічних належать матеріали, актуальність яких обмежена в часі, що зумовлює необхідність їх оновлення за рішенням адміністратора.

До класифікації потокових належать матеріали, які втрачають значимість протягом короткого часу. Їх оновлення здійснюється постійно.

Актуальною формою такої діяльності $€$ розміщення інформаційних матеріалів у нових медіа. Слова «нові медіа» походять від англ. new media, що належать до інтерактивних електронних видань та нових форм комунікації (електронна пошта, соціальні мережі, відео- і фотосервіси, блогінги, форуми тощо). Нові медіа досяжні на цифрових пристроях і дають користувачам можливість участі у створенні та поширенні інформації. Інтерактивність означає спроможність цифрової системи реагувати на дії користувача, у зв'язку з чим на екрані відбуваються зміни візуальних елементів, тексту тощо.

До форми взаємодії належить запрошення представників 3МІ на службові нараді. Вони запрошуються на координаційні нараді, міжвідомчі оперативні наради правоохоронних органів, які присвячені протидії злочинності та шляхам вирішення актуальних проблем.

Якщо в засобах масової інформації будуть висвітлені результати прийнятих рішень, це підвищить ефективність діяльності цих нарад.

\section{Висновок}

Викладене дає змогу зробити висновок, що запропоновані заходи сприятимуть підвищенню ефективності діяльності та авторитету системи прокуратури та засобів масової інформації.

\section{Список використаних джерел:}

1. Клочков В.Г. Взаємодія Генеральної прокуратури України з вищими органами державної влади щодо охорони прав і свобод громадян. Міліиія. 2009. № 4. С. 23; Клочков В.Г. Взаємодія Генеральної прокуратури України з вищими органами державної влади щодо охорони прав і свобод громадян. Вісник прокуратури. 2011. № 5. С. 33-39.

2. Клочков В.Г. Уголовная ответственность за хищение государственного или общественного имущества, совершенное путем присвоения или растраты либо путемзлоупотребления служебным положением. Газета «Слово хлебороб $а »$. Тим, Курская область. 1988. № 38. С. 3; Клочков В.Г. Уголовная ответственность за умышленное тяжкое телесное повреждение. Газета «Слово хлебороба». Тим, Курская область. 1988. № 66. С. 3; Клочков В.Г. Одиннадцать лет тюремного заключения. Газета «За уголь». Донецк. 1993. № 11. С. 4; Клочков В.Г. Мера наказания. Газета «За уголь». Донецк. 1993. № 16. С. 2; Клочков В.Г. Ф е м и д а воздаст по заслугам. Газета «3а уголь». Донецк. 1993. № 17. С. 2; Клочков В.Г. Умышленное убивство. Газета «3a уголь». Донецк. 1993. № 25. С. 4; Клочков В.Г. Возмездие за разбой. Газета «За уголь». Донецк. 1993. № 26. С. 4; Клочков В.Г. Виной всему «зеленый змий». Газета «3a уголь». Донецк. 1993. № 24. С. 4; Клочков В.Г. В пьяном угаре. Газета «За уголь». Донецк. 1993. № 28. С. 4; Клочков В.Г. Розкрадачів державних фондів - до відповіді. Газета «Арсеналещ». Киев. 1995. С. 29; Клочков В.Г. Розкраданню - надійний заслон. «Наша газета». Киев. 1995. С. 2; Клочков В.Г. Следователю нужен помощник. Законность. Москва, 1996. № 4. С. 46; Клочков В.Г. Правова прогалина. Як позбутися. Іменем закону. Київ. 1997. № 8. С. 6; Клочков В.Г. Феміда - марнотратка. Іменем закону. 1997. № 16. С. 8; Клочков В.Г. Вимушене неробство слідчого - втрати державній казні. Іменем закону. Київ. 1997. № 25. С. 7; Клочков В.Г. Про вдосконалення процедури обчислення строків тримання під вартою. Право України. Київ. 1998. № 1 С. 66; Клочков В.Г. Возвращено на волокиту. Милииия. Москва. 1997. № 11. С. 45-46; Клочков В.Г. Підписуємо кожну сторінку документів. Закон і бізнес. № 5. 4 лютого 1998. С. 7; Клочков В.Г. Як спростити і полегшити слідство. Юридичний вісник України. Київ. 8-14 квітня 1999 р. С. 6; Клочков В.Г. Щодо ефективності підвищення попереднього слідства. Право Украӥни. Київ. 1999. № 6. С. 90-91; Клочков В.Г. Додержання законності при затриманні підозрюваного. Вісник прокуратури. 2000. № 1. С. 17; Клочков В.Г. Легалізації грошових коштів, здобутих незаконним шляхом, повинні запобігати правові заходи. Закон і бізнес. Київ. 26.02.2000. № 9. С. 12; Клочков В.Г. Джерела створення прокуратури. Право України. Київ. 2001. № 7. С. 105; Клочков В.Г. Захист прав і свобод людини в діяльності органів прокуратури. Юридичний вісник Украӥни. Київ. 2012. № 20. С. 15. 
3. Клочков В.Г. Проблеми розслідування злочинів та критерії оцінки і показники виміру ефективності роботи прокуратури у сфері довкілля. Матеріали семінару. Дніпропетровськ. 11-12 жовтня 2007. С. 181-186.

4. Клочков В.Г. Музей історії прокуратури України. Право Украӥни. 2006. № 2. С. 138-139;
Клочков В. Історія нашої прокуратури. Українська спілка ветеранів Афганістану. URL: http:// www.usva.org.ua/mambo3/index.php?option= com content\&task=view\&id=4454.

5. Клочков В.Г. Коли на злодії шапка горить, або Що таке крадіжка та як за неї карають. Все про бухгалтерський облік. Київ. 3 квітня 2008. С. 6.

The article considers and emphasizes the necessity of conducting information activities of the Prosecutor General's Office with the mass media for the realization of the principle of publicity, protection and protection of human rights and freedoms, interests of the state.

It is substantiated that forms of interaction of the prosecutor's office with the media are: a press conference, placement of materials in the media; briefing; distribution of press releases; interview; "Round Table"; press tour; placing information materials on the website; performances of employees on television broadcasts and radio programs; placement of information materials in new media; inviting media representatives to a meeting. In particular, informing the population should be combined with an educational direction aimed at overcoming legal nihilism, eliminating the negative and correct perception in the public consciousness of the role and importance of the prosecutor's office in the system of public authorities, the results of law enforcement activities.

It should be noted that the prosecutor is criticized by the mass media. Provocative questions from journalists and other media representatives, categorical requests for answers to criminal proceedings. In this regard, it was determined that prosecutors should have a high level of professionalism, which in turn would contribute to the correct and justified formulation of the answers to the questions posed by journalists and other media representatives, to adhere to the ethics of public speaking and the requirements for providing official and sensitive information.

The article emphasizes the investigation of criminal offenses involving the media. Form of interaction is placement of information materials in new media. In particular, the words "nеw media" are derived from English "nеw media" related to interactive electronic publications and new forms of communication (e-mail, social networks, video and photo services, blogs, forums, etc.). New media is accessible on digital devices and enables users to participate in the creation and dissemination of information. Interactivity means the ability of the digital system to respond to user actions, resulting in changes in visual elements, text, and more on the screen.

Key words: forms of interaction, Prosecutor General's Office, mass media, journalists, publicity, human rights, crime. 